\title{
Letter to the Editor: Response to Luke Fletcher and Philip Peyton regarding "Predictive validity of a novel non-invasive estimation of effective shunt fraction in critically ill patients"
}

\author{
Emma M. Chang ${ }^{1}$, Andrew Bretherick ${ }^{1,2}$, Gordon B. Drummond ${ }^{1}$ and J. Kenneth Baillie ${ }^{1,3^{*}}$ (i)
}

This reply refers to the comment available at https://doi.org/10.1186/ s40635-020-00318-y.

* Correspondence: j.k.baillie@ed.ac.

${ }^{1}$ Anaesthesia, Critical Care and Pain Medicine, Royal Infirmary of Edinburgh, Edinburgh EH16 4SA, UK ${ }^{3}$ The Roslin Institute and Royal (Dick) School of Veterinary Studies, University of Edinburgh, Easter Bush, Edinburgh EH25 9RG, UK Full list of author information is available at the end of the article
To the Editor,

We thank Peyton and Fletcher for their interest in our paper, where we devised a method to infer shunt fraction from a single arterial blood gas sample, with the intention to allow clinical research and prediction without the need for additional invasive measurements, as stated both in the abstract and the main text of our report. Peyton and Fletcher have usefully emphasised this point by citing their own work, in which more invasive samples could be taken. However, it is very likely that the correct derivation of the relationship between the relevant components of the equation has been known and used well before this work: see, for example, the diagrammatic explanation shown in our citation 2 [1]. We do not claim that this simple algebraic rearrangement is original.

As we stated in our paper, our conclusion is that the estimated shunt fraction, although imperfect, is an improvement upon P/F. We recommend its use instead of other measures in situations where $\mathrm{FIO} 2$ is changing.

We thank the authors for spotting the typo in one of the equations in our paper on Effective Shunt (ES). A set of parentheses were dropped in the published version. We have now corrected this.

Best wishes,

Emma Chang, Andrew Bretherick, Gordon Drummond and Kenneth Baillie

\section{Acknowledgements \\ Not applicable}

Authors' contributions

All authors commented and contributed to the final response. The author(s) read and approved the final manuscript.

Funding

Not applicable

Availability of data and materials

Not applicable

() The Author(s). 2020 Open Access This article is licensed under a Creative Commons Attribution 4.0 International License, which permits use, sharing, adaptation, distribution and reproduction in any medium or format, as long as you give appropriate credit to the original author(s) and the source, provide a link to the Creative Commons licence, and indicate if changes were made. The images or other third party material in this article are included in the article's Creative Commons licence, unless indicated otherwise in a credit line to the material. If material is not included in the article's Creative Commons licence and your intended use is not permitted by statutory regulation or exceeds the permitted use, you will need to obtain permission directly from the copyright holder. To view a copy of this licence, visit http://creativecommons.org/licenses/by/4.0/. 
Ethics approval and consent to participate

As this is a response to a letter on our previous work, ethical approval and consent were not required.

Consent for publication

Not applicable

Competing interests

All authors state that they have no potential conflicts of interest to declare relating to this work.

\section{Author details}

${ }^{1}$ Anaesthesia, Critical Care and Pain Medicine, Royal Infirmary of Edinburgh, Edinburgh EH16 4SA, UK. ${ }^{2}$ MRC Institute of Genetics and Molecular Medicine, The University of Edinburgh, Edinburgh EH4 2XU, UK. ${ }^{3}$ The Roslin Institute and Royal (Dick) School of Veterinary Studies, University of Edinburgh, Easter Bush, Edinburgh EH25 9RG, UK.

Received: 12 August 2020 Accepted: 2 September 2020

Published online: 01 October 2020

\section{Reference}

1. Drummond GB, Zhong NS (1983) Inspired oxygen and oxygen transfer during artificial ventilation for respiratory failure. British journal of anaesthesia. 55:3-13

\section{Publisher's Note}

Springer Nature remains neutral with regard to jurisdictional claims in published maps and institutional affiliations.

Submit your manuscript to a SpringerOpen ${ }^{\circ}$ journal and benefit from:

- Convenient online submission

- Rigorous peer review

- Open access: articles freely available online

- High visibility within the field

- Retaining the copyright to your article

Submit your next manuscript at $>$ springeropen.com 